\title{
Front Matter: Volume 11535
}

, "Front Matter: Volume 11535," Proc. SPIE 11535, Remote Sensing Technologies and Applications in Urban Environments V, 1153501 (2 October 2020); doi: 10.1117/12.2584611

SPIE. Event: SPIE Remote Sensing, 2020, Online Only 


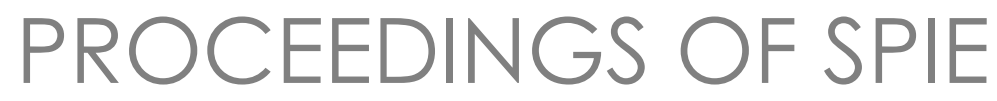

\title{
Remote Sensing Technologies and Applications in Urban Environments $V$
}

\author{
Thilo Erbertseder \\ Nektarios Chrysoulakis \\ Ying Zhang \\ Editors
}

21 - 25 September 2020

Online Only, United Kingdom

Sponsored by

SPIE

Cooperating Organisations

European Optical Society

KTN - Knowledge Transfer Network (United Kingdom)

Technology Scotland (United Kingdom)

Visit Scotland (United Kingdom)

BARSC - British Association of Remote Sensing (United Kingdom)

EARSeL-European Association of Remote Sensing Laboratories (Germany)

ISPRS - International Society for Photogrammetry and Remote Sensing

Published by

SPIE

Volume 11535 
The papers in this volume were part of the technical conference cited on the cover and title page. Papers were selected and subject to review by the editors and conference program committee. Some conference presentations may not be available for publication. Additional papers and presentation recordings may be available online in the SPIE Digital Library at SPIEDigitalLibrary.org.

The papers reflect the work and thoughts of the authors and are published herein as submitted. The publisher is not responsible for the validity of the information or for any outcomes resulting from reliance thereon.

Please use the following format to cite material from these proceedings:

Author(s), "Title of Paper," in Remote Sensing Technologies and Applications in Urban Environments $\checkmark$, edited by Thilo Erbertseder, Nektarios Chrysoulakis, Ying Zhang, Proceedings of SPIE Vol. 11535 (SPIE, Bellingham, WA, 2020) Seven-digit Article CID Number.

ISSN: 0277-786X

ISSN: 1996-756X (electronic)

ISBN: 9781510638839

ISBN: 9781510638846 (electronic)

Published by

SPIE

P.O. Box 10, Bellingham, Washington 98227-0010 USA

Telephone +1 3606763290 (Pacific Time) · Fax +1 3606471445

SPIE.org

Copyright (c) 2020, Society of Photo-Optical Instrumentation Engineers.

Copying of material in this book for internal or personal use, or for the internal or personal use of specific clients, beyond the fair use provisions granted by the U.S. Copyright Law is authorized by SPIE subject to payment of copying fees. The Transactional Reporting Service base fee for this volume is $\$ 21.00$ per article (or portion thereof), which should be paid directly to the Copyright Clearance Center (CCC), 222 Rosewood Drive, Danvers, MA 01923. Payment may also be made electronically through CCC Online at copyright.com. Other copying for republication, resale, advertising or promotion, or any form of systematic or multiple reproduction of any material in this book is prohibited except with permission in writing from the publisher. The CCC fee code is $0277-$ $786 \mathrm{X} / 20 / \$ 21.00$.

Printed in the United States of America by Curran Associates, Inc., under license from SPIE.

Publication of record for individual papers is online in the SPIE Digital Library.

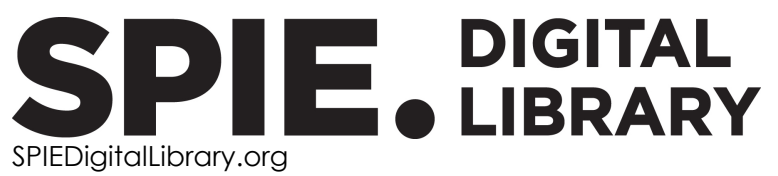

Paper Numbering: Proceedings of SPIE follow an e-First publication model. A unique citation identifier (CID) number is assigned to each article at the time of publication. Utilization of CIDs allows articles to be fully citable as soon as they are published online, and connects the same identifier to all online and print versions of the publication. SPIE uses a seven-digit CID article numbering system structured as follows:

- The first five digits correspond to the SPIE volume number.

- The last two digits indicate publication order within the volume using a Base 36 numbering system employing both numerals and letters. These two-number sets start with $00,01,02,03,04$, 05, 06, 07, 08, 09, OA, OB ... 0Z, followed by 10-1Z, 20-2Z, etc. The CID Number appears on each page of the manuscript. 


\section{Contents}

URBAN AIR QUALITY AND CLIMATE

$1153504 \quad$ Urban landscapes and night time urban heat island [1 1535-2]

1153505 Analysis of urban green spaces and surface temperature using quantitative remote sensing technology in Bangkok [1 1535-3]

1153506 Opportunities to monitor the urban atmospheric furbulence using unmanned aerial system [11535-4]

SMART CITIES

11535 OA Concept of an autonomous mobile robotic system for bridge inspection [11535-8]

$11535 \mathrm{OB} \quad$ Efficient streaming of 3D maps for unmanned navigation: 3D tiling the navigable space and eliminating occluded geometry [11535-9]

URBAN LAND USE

11535 OC Leveraging spatial structure with CapsuleNet for identification of the land use classes [11535-10]

$11535 \mathrm{OE} \quad$ Spatiotemporal monitoring and prediction of land use/land cover changes using CA-Markov chain model: a case study in Orkhon Province, Mongolia [11535-12]

11535 OG Automatic detection of potential buried archaeological sites in Saruq Al-Hadid, United Arab Emirates [11535-14]

URBAN PLANNING

$11535 \mathrm{OH} \quad$ Identifying urban sprawl by night lights a pending issue [11535-15]

11535 0J Time series formation based on VIIRS 24h data [11535-17]

11535 OK From probabilistic to possibilistic fusion and classification approach of satellite multisource and multitemporal images [11535-18]

11535 OM SAR and optical image fusion for urban infrastructure detection and monitoring [11535-20] 
Proc. of SPIE Vol. $115351153501-4$

Downloaded From: https://www.spiedigitallibrary.org/conference-proceedings-of-spie on 26 Apr 2023
Terms of Use: https://www.spiedigitallibrary.org/terms-of-use 